\title{
Kinetics of Antimony(V) Reduction by L-Cysteine. Pharmacological Implications and Application to the Determination of Antimony in Pentavalent Antimonial Drugs
}

\author{
Fernanda B. de Oliveira, ${ }^{a}$ Dante A. Schettini, ${ }^{a}$ Cláudio S. Ferreira, ${ }^{b}$ Breno Rates, ${ }^{a}$ \\ Olguita G. F. Rocha, ${ }^{c}$ Frédéric Frézard ${ }^{a}$ and Cynthia Demicheli ${ }^{*, b}$
}

${ }^{a}$ Departamento de Fisiologia e Biofísica, ICB and ${ }^{b}$ Departamento de Química, ICEx Universidade Federal de Minas Gerais, Av. Antônio Carlos 6627, 31270-901 Belo Horizonte - MG, Brazil

${ }^{c}$ Laboratório de Análise de Traces Metálicos, Fundação Centro Tecnológico de Minas Gerais, Belo Horizonte - MG, Brazil

\begin{abstract}
Como o antimônio é a espécies ativa no medicamento leishmanicida, antimoniato de meglumina (AM), o conhecimento da concentração exata do metal é crítico para o seu uso experimental e clínico. Por outro lado, o papel da cisteína no metabolismo dos antimoniais deve ser esclarecido. No presente trabalho, a reação de redução do $\mathrm{Sb}^{\mathrm{V}}$ pela cisteína foi caracterizada cineticamente. As ordens de reação com relação ao $\mathrm{Sb}$ e à cisteína foram iguais a 1,0 e 3,3, respectivamente. A constante de velocidade da reação de redução foi dependente do $\mathrm{pH}$. Essa reação foi usada para reduzir o $\mathrm{Sb}^{\mathrm{V}}$ no $\mathrm{AM}$, para subseqüente determinação fotométrica do $\mathrm{Sb}^{\mathrm{III}}$ com o cromóforo vermelho de bromopirogalol. Eficiências de redução de $100 \%$ foram alcançadas em pH 3. Soluções apresentando concentrações de Sb baixas como $0,5 \mathrm{mmol} \mathrm{L}^{-1}$ foram dosadas com sucesso. O método foi também aplicado para a determinação de $\mathrm{Sb}$ em formulações lipossomais do AM.
\end{abstract}

Since antimony is the active species in the antileishmanial drug meglumine antimoniate (MA), the knowledge of the exact metal concentration is critical for its experimental and clinical use. On the other hand, the involvement of thiols, such as cysteine (Cys), in the metabolism of this drug remains to be clarified. In the present work, the reduction reaction of $\mathrm{Sb}^{\mathrm{v}}$ by Cys was kinetically characterized. The reaction orders with respect to $\mathrm{Sb}$ and Cys were equal to 1.0 and 3.3 , respectively. The rate constant for the reduction reaction was $\mathrm{pH}$-dependent. This reaction was exploited to effectively reduce $\mathrm{Sb}^{\mathrm{V}}$ in MA, for the subsequent photometric determination of $\mathrm{Sb}^{\text {III }}$ using the chromogen bromopyrogallol red. Reduction efficiencies of $100 \%$ were achieved at $\mathrm{pH}$ 3. Solutions with $\mathrm{Sb}$ concentration as low as $0.5 \mathrm{mmol} \mathrm{L}^{-1}$ were successfully assayed. The method was also applied to the determination of $\mathrm{Sb}$ in liposomal formulations of MA.

Keywords: cysteine, antimony, reduction, liposomes, meglumine antimoniate

\section{Introduction}

Pentavalent antimonials, including meglumine antimoniate, are the drugs of choice for the treatment of leishmaniases. ${ }^{1}$ Since antimony is the active species, the knowledge of the exact metal concentration in commercial formulations is critical for its clinical use. Indeed, its concentration was found to vary from one lot to another in commercial formulations. ${ }^{2}$ Moreover, the determination of $\mathrm{Sb}^{\mathrm{V}}$ concentration in the liposomal formulations of

*e-mail: demichel@netuno.lcc.ufmg.br antimonial drugs is essential for their pharmacological evaluations and therapeutic use. ${ }^{3}$

The most common analytical methods used to determine $\mathrm{Sb}$ are atomic absorption spectroscopy, plasma atomic emission spectrometry, ICP mass spectrometry, neutron activation analysis and voltammetry. ${ }^{2}$ However, these methods usually require the pre-digestion of the organic material present in the sample, are timeconsuming and are neither cost-effective nor appropriate for routine analysis.

A photometric assay has been also proposed for $\mathrm{Sb}^{\mathrm{V}}{ }^{2,4}$ As a first step, $\mathrm{Sb}^{\mathrm{V}}$ was reduced to $\mathrm{Sb}^{\mathrm{III}}$ by iodide in acidic medium. As a second step, iodine was inactivated by 
ascorbic acid and the resulting solution was neutralized with sodium hydroxide. Finally, $\mathrm{Sb}^{\mathrm{III}}$ concentration was determined photometrically, exploiting the specific interaction of $\mathrm{Sb}^{\mathrm{III}}$ with the chromogen bromopyrogallol red (BPR) and the fact that the absorbance of BPR at 560 $\mathrm{nm}$ decreases proportionally to the amount of $\mathrm{Sb}^{\mathrm{III}}$ in the analyte solution, as a consequence of the formation of the 1:1 BPR-Sb ${ }^{\text {III }}$ complex. ${ }^{4}$ However, the quantification of $\mathrm{Sb}^{\mathrm{V}}$ using this procedure was complicated by the fact that its reduction by iodide was only $72 \%$ efficient.

In previous studies, L-cysteine (Cys) was proposed as a pre-reducing agent of $\mathrm{Sb}^{\mathrm{v}}$ for its determination by flowinjection hydride generation atomic-absorption spectrometry and atomic-emission spectrometry. ${ }^{5}$

Since Cys is the predominant thiol in the lysosomes of mammalian cells, ${ }^{6}$ in which Leishmania parasites reside, ${ }^{7}$ and $\mathrm{Sb}^{\mathrm{III}}$ is much more active than $\mathrm{Sb}^{\mathrm{V}}$ against the parasite, ${ }^{8}$ the pharmacological relevance of the reduction reaction of $\mathrm{Sb}^{\mathrm{V}}$ by Cys has been investigated. ${ }^{9}$ It was suggested that this reaction may contribute to the conversion of $\mathrm{Sb}^{\mathrm{V}}$ to $\mathrm{Sb}^{\mathrm{III}}$, previously demonstrated in cell extracts, the vertebrate host and the parasite. ${ }^{10}$ The reduction of $\mathrm{Sb}^{\mathrm{v}}$ by Cys was found to occur at $37^{\circ} \mathrm{C}$ at both $\mathrm{pH} 5$ and $\mathrm{pH} 7$, but was favored at acidic $\mathrm{pH} .{ }^{9}$ Other physiologically-relevant thiols were also evaluated: ${ }^{9}$ glutathione, which is the main thiol in the cytosol of mammalian cells; ${ }^{11}$ and the glutathione-spermine conjugate, trypanothione $\left(\mathrm{T}(\mathrm{SH})_{2}\right)$, which is the predominant thiol within the parasite. ${ }^{12}$ Strikingly, the initial rates of reduction of $\mathrm{Sb}^{\mathrm{v}}$ were much greater in the presence of Cys and $\mathrm{T}(\mathrm{SH})_{2}$ than in the presence of glutathione. ${ }^{9}$ These data supported the hypothesis that $\mathrm{Sb}^{\mathrm{V}}$ is reduced in vivo by $\mathrm{T}(\mathrm{SH})_{2}$ within Leishmania parasites and by Cys within the acidic compartments of mammalian cells where the parasites reside. On the other hand, recent studies have also suggested the participation of enzymes in the process of reduction of $\mathrm{Sb}^{\mathrm{V}}$ to $\mathrm{Sb}^{\mathrm{III} 13}$ and the possible role of $\mathrm{Sb}^{\mathrm{V}}$-ribonucleoside complexes in the mode of action of pentavalent antimonials. ${ }^{14}$

Further progress towards the elucidation of the pharmacological importance of Cys, as well as the use of this thiol in analytical procedures, depends on the full kinetic characterization of this reaction.

In the present work, the reaction of $\mathrm{Sb}^{\mathrm{V}}$ with Cys was kinetically characterized. As a consequence, a new insight into the pharmacological role of Cys was achieved and the photometric assay for $\mathrm{Sb}^{\mathrm{V}}$ was improved. Cys was also chosen for this assay because of its low cost and the relatively high rate of reduction promoted by this thiol. The resulting method was successfully applied to the determination of $\mathrm{Sb}$ in meglumine antimoniate and in liposomal formulations of the antimonial compound.

\section{Experimental}

Photometric determination of S $b^{I I I}$ and influence of Cys concentration

The procedure used to determine $\mathrm{Sb}^{\mathrm{II}}$ was described in detail previously. ${ }^{9}$ It is based on the specific interaction of $\mathrm{Sb}^{\mathrm{III}}$ with BPR. The absorbance of BPR at $560 \mathrm{~nm}$ decreases proportionally to the amount of $\mathrm{Sb}^{\mathrm{III}}$ in the analyte solution, as a consequence of the formation of the 1:1 BPR-Sb ${ }^{\text {III }}$ complex. Briefly, $0.5 \mathrm{~mL}$ of analyte solution was prepared from $0.1 \mathrm{~mL}$ of $0.1 \mathrm{~mol} \mathrm{~L}^{-1}$ phosphate, $0.01 \mathrm{~mL}$ of $5 \%(\mathrm{~m} / \mathrm{v})$ tartrate, $0.05 \mathrm{~mL}$ of $350 \mu \mathrm{mol} \mathrm{L}^{-1} \mathrm{BPR}$ solution in 1:1 water/ethanol $(\mathrm{v} / \mathrm{v})$ and $0.34 \mathrm{~mL}$ of water. The $\mathrm{pH}$ was then adjusted to 6.8 using sodium hydroxide. The absorbance was registered, at $560 \mathrm{~nm}$ before $\left(A_{\mathrm{o}}\right)$ and after $\left(A_{\mathrm{m}}\right)$ adding $5 \mu \mathrm{L}$ of the sample to be analyzed, so as to obtain a $\mathrm{Sb}^{\mathrm{III}}$ concentration in the range of $1.2 \times 10^{-6}$ to $25 \times 10^{-6} \mathrm{~mol} \mathrm{~L}^{-1}$. For each experiment, a calibration curve was established, in the presence of the same amount of Cys as that used in the reduction step. Potassium antimony(III) tartrate was used as the source of $\mathrm{Sb}^{\mathrm{II}}$ and the change in BPR absorbance $\left(A_{\mathrm{o}}-A_{\mathrm{m}}\right)$ was plotted as a function of $\mathrm{Sb}^{\mathrm{III}}$ concentration.

\section{Materials}

N-methyl-D-glucamine (NMG, 99\%), $\mathrm{SbCl}_{5}$ (99\%), bromopyrogallol red (BPR, 70\%) and potassium antimony(III) tartrate (>99\%) were obtained from Aldrich Chemical Co. (Milwaukee, Wis) and potassium hexahydroxoantimoniate $\left(\mathrm{KSb}(\mathrm{OH})_{6},>99 \%\right)$ from Fluka Chemie $\mathrm{GmbH}$ (Switzerland). Cholesterol (CHOL), dicetylphosphate (DCP), L-cysteine (Cys, 98\%) and Triton X-100 (>99\%) were purchased from Sigma Co. (St. Louis, MO, USA). Distearoylphosphatidylcholine (DSPC) was obtained from Avanti Polar Lipids Inc. (Alabaster, AL, USA). An antimony standard $\left(\mathrm{SbCl}_{3}\right.$ in $24 \% \mathrm{HCl}$, Titrisol $\left.{ }^{\circledR}\right)$ was purchased from MERCK (São Paulo, SP, Brazil). Double-distilled-deionized water was used throughout the experiments.

\section{Preparation of meglumine antimoniate and of liposomal formulations}

Meglumine antimoniate was synthesized, according to Demicheli et al. ${ }^{15}$ from an equimolar mixture in water of NMG and freshly precipitated and hydrated antimony pentoxide obtained from $\mathrm{SbCl}_{5}$ previously hydrolyzed in 
water. After precipitation with acetone, the resulting product was dried. Meglumine antimoniate product contained $29 \%$ of Sb by weight, as determined by inductively coupled plasma optical emission spectrometry (ICP-OES) using a Perkin Elmer plasma emission spectrometer, model Optima 3000.

Liposomal formulations of meglumine antimoniate, DRVs and FDELs, were prepared from DSPC, CHOL and DCP (molar ratio of 5:4:1) in the absence or presence of sucrose, as described previously. ${ }^{3}$ The concentration of $\mathrm{Sb}$ in the liposomal samples was determined by ICP-OES, after submission of the samples to digestion with concentrated nitric acid. Sb concentrations in the range of 8 to $16 \mathrm{~g} \mathrm{~L}^{-1}$ and $\mathrm{Sb} /$ lipid mass ratio in the range of 0.2 to 0.35 were found.

\section{Determination of the linear range of the photometric assay and of the interference of Cys}

The linear range and sensitivity of the method were evaluated through the linear regression of the $\left(A_{\mathrm{o}}-A_{\mathrm{m}}\right) v s$. [Sb $\left.{ }^{\text {III }}\right]$ data, in the concentration range of $1.2 \times 10^{-6}$ to $25 \times 10^{-6} \mathrm{~mol} \mathrm{~L}^{-1}$, and the determination of the linear correlation coefficient and the slope of the curve. To determine the interference of Cys on these parameters, the thiol was introduced at varying concentrations $(0,0.8$, 2 or $4 \mathrm{mmol} \mathrm{L}^{-1}$ ) in the analyte BPR solution.

\section{Determination of the partial orders of the reduction reaction}

Two different experiments were performed. In the first one, $\mathrm{Sb}$ concentration was kept constant at $1 \mathrm{mmol} \mathrm{L}^{-1}$ and Cys concentration was varied form 5 to $12.5 \mathrm{mmol} \mathrm{L}^{-1}$. In the second one, Cys concentration was kept constant at 10 mmol L-1 and $\mathrm{Sb}$ concentration was varied from 0.5 to 2 mmol L-1. All aqueous solutions contained $0.1 \mathrm{~mol} \mathrm{~L}^{-1} \mathrm{KCl}$, $0.02 \mathrm{~mol} \mathrm{~L}^{-1}$ phosphate and $0.02 \mathrm{~mol} \mathrm{~L}^{-1}$ acetate. The $\mathrm{pH}$ was adjusted to 5 . Reaction was run at $37^{\circ} \mathrm{C}$ and under argon to prevent the oxidation of Cys by oxygen. The initial rate of $\mathrm{Sb}^{\mathrm{v}}$ reduction $\left(V_{\mathrm{i}}\right)$ was calculated from the concentration of $\mathrm{Sb}^{\mathrm{III}}$ determined photometrically, as described above, in the initial conditions of reaction. The reaction was considered in initial conditions when the amount of reduced $\mathrm{Sb}$ did not exceed $10 \%$ of the total $\mathrm{Sb}^{\mathrm{II}}$ amount at equilibrium. The reaction partial orders, $n$ and $\mathrm{m}$, with respect to Cys and $\mathrm{Sb}$ respectively, were determined from the following equations:

$$
\begin{aligned}
& V_{\mathrm{i}}=k_{\mathrm{ap}}[\mathrm{Cys}]^{\mathrm{n}}[\mathrm{Sb}]^{\mathrm{m}} \\
& \ln \left(V_{\mathrm{i}}\right)=\mathrm{n} \ln ([\mathrm{Cys}])+\mathrm{m} \ln ([\mathrm{Sb}])+\ln \left(k_{\mathrm{ap}}\right)
\end{aligned}
$$

where $[\mathrm{Cys}]=$ initial molar concentration of Cys, $[\mathrm{Sb}]=$ initial molar concentration of $\mathrm{Sb}$ and $k_{\mathrm{ap}}=$ apparent rate constant for reduction.

\section{Determination of the activation energy of the reduction reaction}

The reaction medium contained $5 \mathrm{mmol} \mathrm{L}^{-1} \mathrm{Cys}$ and 1 mmol L-1 $\mathrm{Sb}$, in the presence of $0.1 \mathrm{~mol} \mathrm{~L}^{-1} \mathrm{KCl}, 0.02 \mathrm{~mol}$ $\mathrm{L}^{-1}$ phosphate and $0.02 \mathrm{~mol} \mathrm{~L}^{-1}$ acetate. The $\mathrm{pH}$ was adjusted to 5 and solutions were kept under argon. The reaction was run at $15^{\circ} \mathrm{C}, 25^{\circ} \mathrm{C}, 37^{\circ} \mathrm{C}$ or $47^{\circ} \mathrm{C}$. The apparent rate constants for reduction $\left(k_{\text {ap }}\right)$ were calculated using equation (1) and the concentration of $\mathrm{Sb}^{\mathrm{III}}$, determined photometrically, as described above, in the initial conditions of reaction. The activation enthalpy $\left(\Delta H^{*}\right)$ was obtained from the slope of the plot of arrhenius equation:

$\ln \left(k_{\text {ap }}\right)=\ln \left[\omega \exp \left(\Delta S^{*} / R\right)\right]-\Delta H^{*} / R T$

\section{Influence of $\mathrm{pH}$ on the rate of $S b^{V}$ reduction}

The reaction medium contained $5 \mathrm{mmol} \mathrm{L}{ }^{-1}$ Cys, 1 mmol L-1 Sb, $0.1 \mathrm{~mol} \mathrm{~L}^{-1} \mathrm{KCl}, 0.02 \mathrm{~mol} \mathrm{~L}^{-1}$ phosphate and $0.02 \mathrm{~mol} \mathrm{~L}^{-1}$ acetate. Different samples were prepared with a pH value varying from 3 to 6 (with intervals of $0.25 \mathrm{pH}$ units) and the reaction was run under argon. The apparent rate constant for reduction $\left(k_{\text {ap }}\right)$ was calculated using equation (1) and the concentration of $\mathrm{Sb}^{\mathrm{III}}$ determined photometrically, as described above, in the initial conditions of reaction.

Efficiency of $S b^{V}$ reduction in meglumine antimoniate: influence of $\mathrm{pH}$, time of reaction, $\mathrm{Sb}^{V}$ concentration and temperature

To evaluate the influence of $\mathrm{pH}$, temperature, time of reaction and $\mathrm{Sb}^{\mathrm{v}}$ concentration on the efficiency of $\mathrm{Sb}^{\mathrm{V}}$ reduction in meglumine antimoniate, aqueous solutions containing meglumine antimoniate and $0.05 \mathrm{~mol} \mathrm{~L}^{-1} \mathrm{Cys}$ were freshly prepared and reaction was run under argon.

In the study of the influence of $\mathrm{pH}$ and time of reaction, meglumine antimoniate was added at $0.5 \mathrm{mmol} \mathrm{L}^{-1}$ of $\mathrm{Sb}$, $\mathrm{pH}$ was adjusted at 5,6 or 7 and the reaction was run at $50^{\circ} \mathrm{C}$ for 1 or $3 \mathrm{~h}$.

In the study of the influence of $\mathrm{Sb}^{\mathrm{v}}$ concentration and temperature, meglumine antimoniate was added at a $\mathrm{Sb}$ concentration varying from 0.05 to $0.5 \mathrm{mmol} \mathrm{L}^{-1}$, $\mathrm{pH}$ was adjusted to 3 and the reaction was run for $1 \mathrm{~h}$ at $25^{\circ} \mathrm{C}$ or $50^{\circ} \mathrm{C}$. 
Each sample was prepared in quadruplicates. The concentration of $\mathrm{Sb}^{\mathrm{III}}$ was then determined using the BPR photometric assay, as described above.

\section{Procedure for determination of $\mathrm{Sb}^{v}$ in samples of liposomal meglumine antimoniate}

Samples of liposomal meglumine antimoniate, prepared as described above at a lipid concentration typically in the range of 30 to $65 \mathrm{~g} \mathrm{~L}^{-1}$, were diluted fivefold in water and then mixed with an equal volume of $20 \%(\mathrm{~m} / \mathrm{v})$ Triton X-100 aqueous solution. The mixture was then incubated for $1 \mathrm{~h}$ at $60^{\circ} \mathrm{C}$ to induce the release of the encapsulated antimonial compound. $50 \mu \mathrm{L}$ of the resulting suspension was then mixed with $250 \mu \mathrm{L}$ of a freshly-prepared Cys solution at $\mathrm{pH} 3$ and $200 \mu \mathrm{L}$ of water. The resulting solution was then immediately incubated for $1 \mathrm{~h}$ at $60^{\circ} \mathrm{C}$ under argon to promote the reduction of $\mathrm{Sb}^{\mathrm{V}}$ into $\mathrm{Sb}^{\mathrm{III}}$. The concentration of $\mathrm{Sb}^{\mathrm{III}}$ was then determined photometrically, as described above.

To determine the possible interference of the liposome matrix (selectivity) and the precision of the method, samples with varying concentrations of $\mathrm{Sb}$ (from Titrisol $^{\circledR}$ standard) (0.04, 0.08, 0.12, 0.16 and $\left.0.2 \mathrm{~mol} \mathrm{~L}^{-1}\right)$ were prepared in water, in the absence or presence of empty liposomes made from DSPC, CHOL and DCP (molar ratio of 5:4:1) at a final lipid concentration of 65 $\mathrm{g} \mathrm{L}^{-1}$. For each $\mathrm{Sb}$ concentration, seven identical samples were prepared independently. These samples were treated as described above (treatment with Triton X-100 and Cys). After measurement of the sample-induced change in BPR absorbance, $\left(A_{\mathrm{o}}-A_{\mathrm{m}}\right)$ was plotted as a function of the final Sb concentration in the cuvet. The Snedecor F Test was then applied to compare the variances, followed by the student $\mathrm{t}$ Test to compare the means. The mean $(M)$ and standard deviation $(D)$ of the measurements obtained for each $\mathrm{Sb}$ concentration were used to calculate the relative standard deviation $(\% R S D)$ for a confidence level of $95 \%$, as follows: $\% R S D=(D / M) \times 100$.

To evaluate the accuracy of the method, samples with $\mathrm{Sb}$ concentrations (from Titrisol ${ }^{\circledR}$ standard) of 0.02 (sample 1), 0.08 (sample 2) and $0.16 \mathrm{~mol} \mathrm{~L}^{-1}$ (sample 3) were prepared in the presence of empty liposomes made from DSPC, CHOL and DCP (molar ratio of 5:4:1) at a final lipid concentration of $65 \mathrm{~g} \mathrm{~L}^{-1}$. To samples 1, 2 and 3, known amounts of $\mathrm{Sb}$ were added at the final concentrations of $0.02,0.04$ and $0.04 \mathrm{~mol} \mathrm{~L}^{-1}$, respectively. These samples were then treated as described above (treatment with Triton $\mathrm{X}-100$ and Cys) and $\mathrm{Sb}^{\mathrm{III}}$ concentration was determined photometrically using the BPR assay. The recovery was then calculated from $\% R=\left(C_{1}-C_{2} / C_{3}\right)$, where $C_{1}=\mathrm{Sb}$ concentration determined in the sample after addition, $C_{2}=\mathrm{Sb}$ concentration determined in the sample before addition; $C_{3}=$ concentration of added $\mathrm{Sb}$. In addition to the study of $\mathrm{Sb}$ recovery, the values of $\mathrm{Sb}^{\mathrm{V}}$ concentration determined for four different liposomal preparations of meglumine antimoniate were compared to those obtained by the classical ICP-OES method.

\section{Results and Discussion}

\section{Kinetics of $S b^{V}$ reduction by Cys}

Previous studies have established that Cys can promote the reduction of $\mathrm{Sb}^{\mathrm{V}}$ into $\mathrm{Sb}^{\mathrm{III}}$ in potassium antimoniate and meglumine antimoniate,, 59 however, this reaction was not fully characterized kinetically.

As a first step, experiments were performed to determine the partial orders of the reaction with respect to Cys and antimoniate ( $\mathrm{Sb}$ ). Figures $1 \mathrm{a}$ and $1 \mathrm{~b}$ show the plots of $\ln \left(V_{\mathrm{i}}\right)$ as a function of $\ln ([\mathrm{Cys}])$ and $\ln ([\mathrm{Sb}])$, respectively. Linear relationships were obtained and the slopes gave the partial orders of reaction: $\mathrm{m}=3.26 \pm 0.16$ and $\mathrm{n}=1.05 \pm 0.07$. Therefore, the following relation could be established: $V_{\mathrm{i}}=k_{\mathrm{ap}}[\mathrm{Cys}]^{3.3}[\mathrm{Sb}]$

Using these data, the apparent rate constant for $\mathrm{Sb}^{\mathrm{V}}$ reduction $\left(k_{\text {ap }}\right)$ could also be estimated at pH 5 and $37^{\circ} \mathrm{C}$ : $k_{\text {ap }}=256 \pm 37\left(\mathrm{~mol} \mathrm{~L}^{-1}\right)^{-3.3} \mathrm{~s}^{-1}$

It is noteworthy that it is the first time that this reaction is fully characterized kinetically. The demonstration of the strong dependence of the rate of reaction upon the concentration of Cys is an important contribution of the present study. The high order of the reaction in Cys, together with the fact that it is fractional, indicates that we are not dealing with a simple single-step mechanism. Although two Cys molecules would theoretically be sufficient to promote the reduction of $\mathrm{Sb}^{\mathrm{V}}$ into $\mathrm{Sb}^{\mathrm{III}}$, the high order of reaction in Cys suggests that at least one additional Cys molecule is involved in the composition of the rate-limiting transition state.

Determination of $k_{\text {ap }}$ at different temperatures and the plot of arrhenius equation (equation 3), as shown in Figure 2 , allowed for the calculation of the activation enthalpy for $\mathrm{Sb}^{\mathrm{V}}$ reduction: $\Delta H^{*}=42.4 \pm 2.8 \mathrm{~kJ} \mathrm{~mol}^{-1}$.

As the rate of $\mathrm{Sb}^{\mathrm{V}}$ reduction was found previously to depend on $\mathrm{pH},{ }^{9} k_{\text {ap }}$ was determined at different $\mathrm{pH}$ values in the range of 3 to 6 . Figure 3 displays the plot of $k_{\text {ap }}$ as a function of $\mathrm{pH}$. $k_{\text {ap }}$ was found to be maximum at a $\mathrm{pH}$ value of about 4.7 and $k_{\text {ap }}$ was significantly lower at both lower and higher values of $\mathrm{pH}$.

When analyzing the $\mathrm{pH}$-rate profile according to Loudon, ${ }^{16}$ one can identify two upward bends at $\mathrm{pH}$ values 


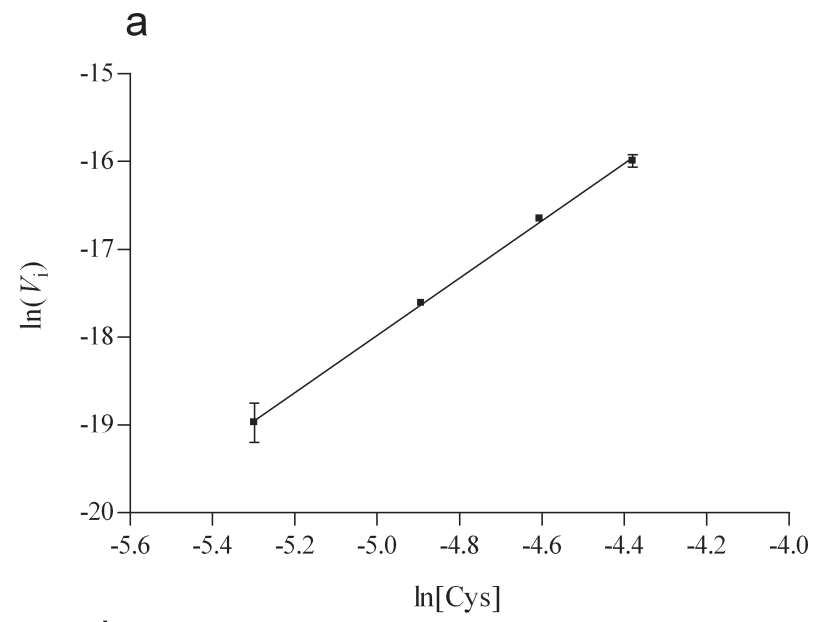

b

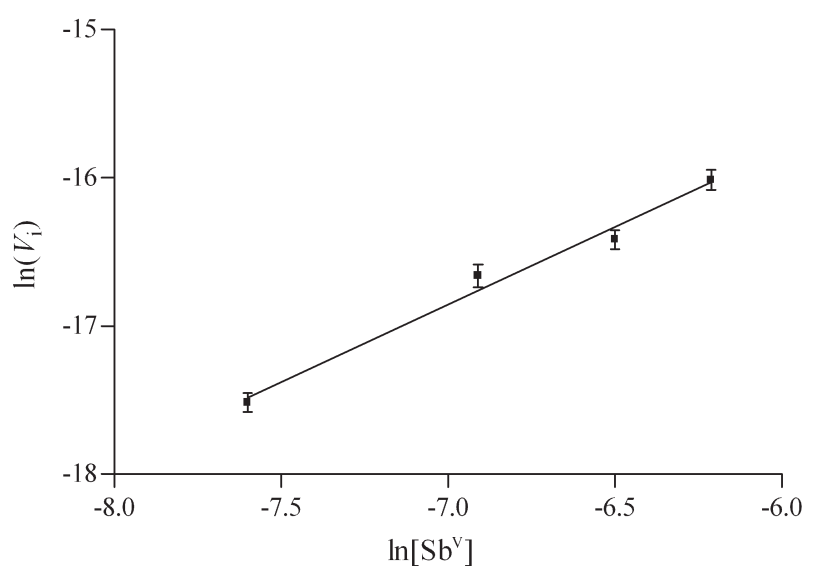

Figure 1. Plots of the logarithm of the initial rate of reduction of $\mathrm{Sb}^{\mathrm{v}}$ by Cys $\left(V / \mathrm{mol} \mathrm{L}^{-1} \mathrm{~s}^{-1}\right)$ determined at $\mathrm{pH} 5$ and $37^{\circ} \mathrm{C}$ as a function of the logarithm of Cys molar concentration (a) $\left([\mathrm{Sb}]=1 \mathrm{mmol} \mathrm{L}^{-1}\right)$ and $\mathrm{Sb}$ molar concentration (b) $\left([\mathrm{Cys}]=10 \mathrm{mmol} \mathrm{L}^{-1}\right)$. $\mathrm{Sb}^{\mathrm{V}}$ was presented as potassium antimoniate. Data are shown as means $\pm \mathrm{SD}(\mathrm{n}=3)$.

of about 4.0 and 5.5 , that can be attributed to changes in the mechanism of the reaction. Two downward bends were also observed at $\mathrm{pH}$ values of about 4.6 and 5.1, that may be explained, either by a titration of the reagents and/or by a change in rate-limiting step. ${ }^{16}$ Titration of the reagents Cys and $\mathrm{Sb}^{v}$ is unlikely, especially if we consider their reported $\mathrm{p} K_{\mathrm{a}}$ values. The carboxylic acid group of Cys has a $\mathrm{p} K_{\mathrm{a}}$ in range of 1.7 to 2.1. Moreover, $\mathrm{Sb}(\mathrm{OH})_{5}$ and $\mathrm{Sb}(\mathrm{OH})_{6}^{-}$are considered to be the predominant acid and base $\mathrm{Sb}^{\mathrm{V}}$ species in aqueous solution, ${ }^{17}$ which are in equilibrium according to the following reaction $\left(\mathrm{p} K_{\mathrm{a}}\left\{\left[\mathrm{Sb}(\mathrm{OH})_{6}^{-}\right] /\left[\mathrm{Sb}(\mathrm{OH})_{5}\right]\right\} \approx 2.7\right)$ :

$$
\mathrm{Sb}(\mathrm{OH})_{5}+\mathrm{H}_{2} \mathrm{O} \leftrightarrow \mathrm{Sb}(\mathrm{OH})_{6}^{-}+\mathrm{H}^{+}
$$

Since Cys is considered as the predominant thiol in the lysosomes of mammalian cells ${ }^{6}$ and Leishmania parasites reside inside the phagolysosomes of macrophages, ${ }^{7}$ Cys may be involved in the in vivo reduction of

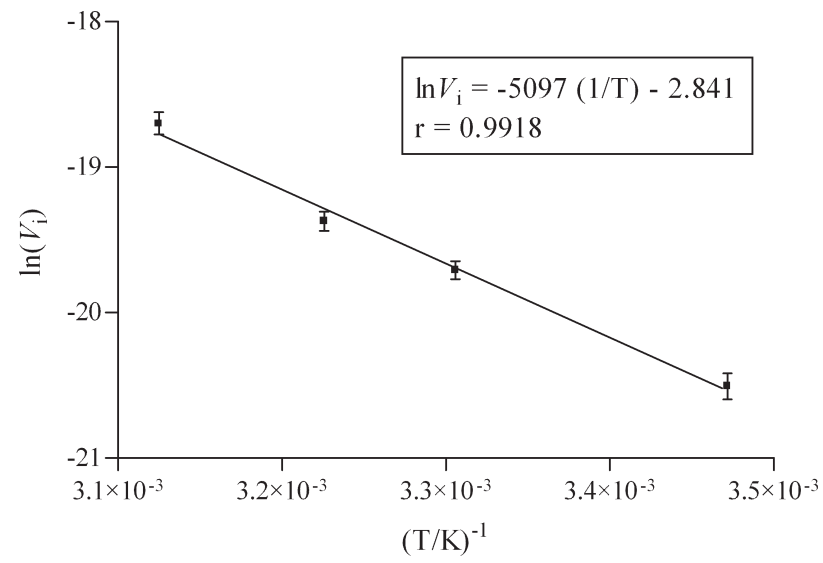

Figure 2. Arrhenius plot obtained with the initial rate of $\mathrm{Sb}^{\mathrm{v}}$ reduction $\left(V_{\mathrm{i}} / \mathrm{mol} \mathrm{L}^{-1} \mathrm{~s}^{-1}\right) .[\mathrm{Sb}]=1 \mathrm{mmol} \mathrm{L}^{-1},[\mathrm{Cys}]=5 \mathrm{mmol} \mathrm{L}^{-1}, \mathrm{pH}$ 5. Data are shown as means $\pm \mathrm{SD}(\mathrm{n}=3)$.

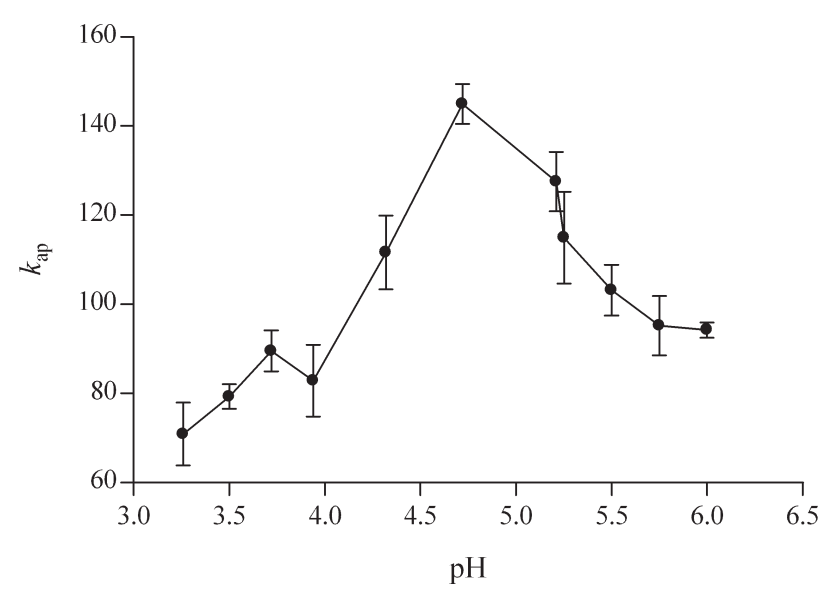

Figure 3. Influence of $\mathrm{pH}$ on the apparent rate constant $\left(k_{\mathrm{ap}} /\left(\mathrm{mol} \mathrm{L}^{-1}\right)^{-3.3} \mathrm{~s}^{-1}\right)$ for the reduction of $\mathrm{Sb}^{\mathrm{v}}$ by Cys at $37^{\circ} \mathrm{C}$. $\mathrm{Sb}^{\mathrm{v}}$ was presented as potassium antimoniate. Data are shown as means $\pm \operatorname{SD}(n=3)$.

$\mathrm{Sb}^{\mathrm{V}}$ into more toxic $\mathrm{Sb}^{\text {III } 10}$ and, ultimately, in the mechanism of action of pentavalent antimonial drugs againt leishmaniasis.

The $\mathrm{pH}$ value of the lysosomes, in the range of 4.5 to 5 , is expected to favour the reduction reaction. However, whether or not such a reaction effectively takes place, depends on the local concentrations of $\mathrm{Sb}$ and $\mathrm{Cys}$ and on the state of complexation of $\mathrm{Sb}$. As reported previously, the complexation of $\mathrm{Sb}^{\mathrm{v}}$ with $\mathrm{N}$-methyl-D-glucamine slows down the reduction reaction by a 7 -fold factor. ${ }^{9}$ On the other hand, a recent study aimed to the speciation of $\mathrm{Sb}$ in the serum and urine of humans submitted to chemotherapy with meglumine antimoniate indicated a partial dissociation of the drug into antimoniate. ${ }^{18}$ The concentration of $\mathrm{Sb}$ in the lysosomes of infected cells during antimonial chemotherapy is not known precisely. However, considering that the $\mathrm{Sb}$ concentration achieved in the serum of humans during treatment is about 0.15 mmol L${ }^{-1}$ and that mammalian cells exposed to meglumine 
antimoniate exhibit comparable intra- and extra-cellular concentrations at equilibrium, ${ }^{19,20}$ one can assume a $\mathrm{Sb}$ concentration of $0.15 \mathrm{mmol} \mathrm{L}^{-1}$ inside the lysosomes. Since the effective concentration of $\mathrm{Sb}^{\mathrm{III}}$ against Leishmania parasites is about $0.04 \mathrm{mmol} \mathrm{L}^{-1}$ and macrophages retain $\mathrm{Sb}$ for at least three days after a short exposure to the antimonial drug, ${ }^{8,21}$ one can infer that a minimum rate of reduction of $0.013 \mathrm{mmol} \mathrm{L}^{-1}$ day $^{-1}$ would be necessary to achieve efficacy against the intracellular parasite. Using equation (1) and $k_{\mathrm{ap}}=256\left(\mathrm{~mol} \mathrm{~L}^{-1}\right)^{-3.3} \mathrm{~s}^{-1}\left(37^{\circ} \mathrm{C}, \mathrm{pH} 5\right)$ and assuming a $\mathrm{Sb}^{\mathrm{V}}$ concentration of $0.15 \mathrm{mmol} \mathrm{L}^{-1}$, one can estimate that the intralysosomal Cys concentration should be at least $3 \mathrm{mmol} \mathrm{L}^{-1}$ to reach such a rate of reduction.

Values for the concentration of Cys inside lysosomes have not been published so far, however, considering the millimolar range of glutathione concentration in the cytosol (2 to $\left.10 \mathrm{mmol} \mathrm{L}^{-1}\right),{ }^{11}$ one would expect a similar range of Cys concentration.

Application of the reduction reaction of $S b^{v}$ by Cys to the determination of $\mathrm{Sb}$ in meglumine antimoniate

In the present study, a novel procedure has been evaluated for the determination of $\mathrm{Sb}^{\mathrm{v}}$ in meglumine antimoniate. Two steps are proposed. As a first step, $\mathrm{Sb}^{\mathrm{v}}$ is reduced to $\mathrm{Sb}^{\mathrm{III}}$ by Cys. As a second step, $\mathrm{Sb}^{\mathrm{III}}$ concentration is determined exploiting the specific interaction of $\mathrm{Sb}^{\mathrm{III}}$ with BPR. ${ }^{4}$

Since Cys and $\mathrm{Sb}^{\mathrm{III}}$ are expected to form a $\mathrm{Sb}(\mathrm{Cys})_{3}$ complex, ${ }^{22}$ competition should take place between Cys and BPR for the binding of $\mathrm{Sb}^{\mathrm{III}}$. This led us to evaluate

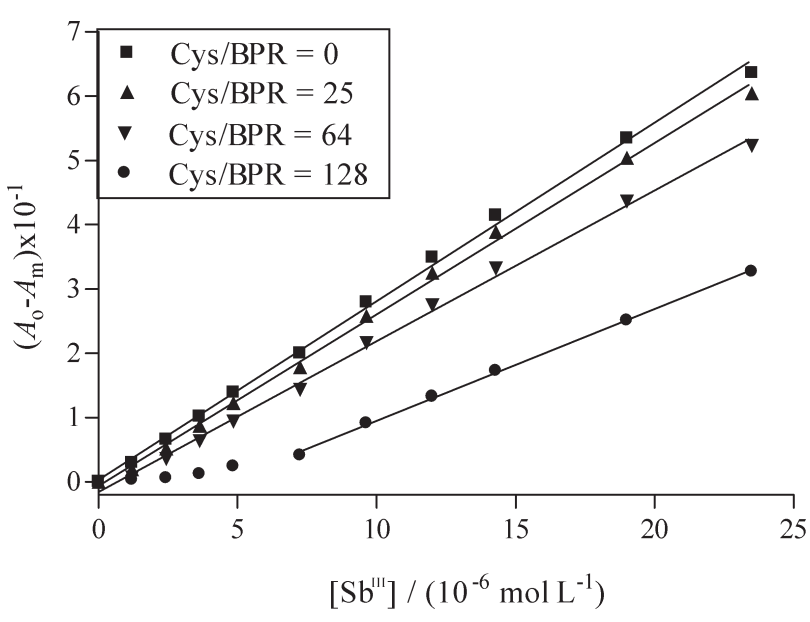

Figure 4. Influence of the Cys/BPR ratio on the calibration curve, representing the change in BPR absorbance at $560 \mathrm{~nm}\left(A_{0}-A_{\mathrm{m}}\right)$ as a function of $\mathrm{Sb}^{\mathrm{III}}$ concentration. Linear curve fits were performed using all the data in each condition, except for the Cys/BPR ratio of 128 that used [Sb] from $7.25 \times 10^{-6} \mathrm{~mol} \mathrm{~L}^{-1}$. the influence of different concentrations of Cys on the linearity and sensitivity of the photometric assay. Figure 4 shows the plot of the change in BPR absorbance as a function of $\mathrm{Sb}^{\mathrm{II}}$ concentration, in the presence of varying concentrations of Cys. In the absence of Cys, the method was linear in the range of $1.2 \times 10^{-6}$ to $23.5 \times 10^{-6} \mathrm{~mol} \mathrm{~L}^{-1}$ with a correlation coefficient of 0.9989 . When the Cys/BPR molar ratio was increased from 0 to 64, the slope of the curve suffered a slight diminution but its linearity remained almost unaffected (correlation coefficient $>0.9984$ ). On the other hand, at the Cys/BPR molar ratio of 128 , the slope decreased sharply and the linearity was maintained only in the range of $7.25 \times 10^{-6}$ to $23.5 \times 10^{-6}$ mol L-1. According to these data, Cys/BPR molar ratio less or equal than 64 should be used in the photometric assay and the calibration curve should be established in the presence of the same amount of Cys as that used in the reduction step.

One of the objectives of the present study was to identify some experimental conditions leading to $100 \%$ of $\mathrm{Sb}^{\mathrm{v}}$ reduction in meglumine antimoniate. A previous study has established that the initial rate of $\mathrm{Sb}^{\mathrm{v}}$ reduction was about 7-fold lower with meglumine antimoniate than with potassium antimoniate, ${ }^{9}$ most probably because $\mathrm{Sb}$ atom is less accessible in its complexed form. ${ }^{15}$

Figure 5 shows the efficiency of $\mathrm{Sb}^{\mathrm{v}}$ reduction achieved, when meglumine antimoniate at $0.5 \mathrm{mmol} \mathrm{L}^{-1}$ was incubated with $50 \mathrm{mmol} \mathrm{L}^{-1} \mathrm{Cys}$ at $50{ }^{\circ} \mathrm{C}$. Strikingly, the reduction of $\mathrm{Sb}^{\mathrm{v}}$ reached an efficiency of $100 \%$ only at $\mathrm{pH} 3$. At $\mathrm{pH} 5$ and 7 , even after $3 \mathrm{~h}$ of incubation, the reduction of $\mathrm{Sb}^{\mathrm{v}}$ was not complete. These results indicate a strong $\mathrm{pH}$-dependence of the reaction and suggest a higher reactivity of $\mathrm{Sb}(\mathrm{OH})_{5}$, the acid form of $\mathrm{Sb}^{\mathrm{V}}$.

The range of $\mathrm{Sb}$ concentration in the sample which leads to $100 \%$ of $\mathrm{Sb}^{\mathrm{v}}$ reduction is also an important data to be determined. Figure 6 shows the efficiency of $\mathrm{Sb}^{\mathrm{V}}$ reduction achieved, when meglumine antimoniate was incubated with $50 \mathrm{mmol} \mathrm{L}^{-1}$ of Cys at Sb concentration varying from 0.05 to $0.5 \mathrm{mmol} \mathrm{L}^{-1}$ (pH $3,25^{\circ} \mathrm{C}$ or $50^{\circ} \mathrm{C}$ ). It can be observed that the efficiency of $\mathrm{Sb}^{\mathrm{V}}$ reduction was less than $100 \%$ at $\mathrm{Sb}$ concentration below $0.25 \mathrm{mmol}$ $\mathrm{L}^{-1}$. This concentration limit was identical at $25{ }^{\circ} \mathrm{C}$ and $50{ }^{\circ} \mathrm{C}$. From this data, specific experimental conditions allowing for the determination of $\mathrm{Sb}^{\mathrm{v}}$ in meglumine antimoniate could be defined. Those are summarised in Table 1.

It is noteworthy that these conditions may also apply to the determination of $\mathrm{Sb}$ in other $\mathrm{Sb}^{\mathrm{V}}$ complexes, even though the method would still require validation.

When compared to the method proposed by Rath et $a l .,^{2}$ our method presents the significant advantages of 
Table 1. Recommended experimental conditions for the determination of $\mathrm{Sb}^{\mathrm{v}}$ in meglumine antimoniate, either free or encapsulated in liposomes

\begin{tabular}{|c|c|c|}
\hline & Meglumine antimoniate & $\begin{array}{l}\text { Liposomal } \\
\text { Meglumine antimoniate }\end{array}$ \\
\hline Step 1. Lysis of liposomes & - & $\begin{array}{c}{[\text { Triton X-100] }=10 \%(\mathrm{~m} / \mathrm{v})} \\
{[\text { Phospholipid }]<15 \mathrm{~g} \mathrm{~L}^{-1} 1 \mathrm{~h}, 60{ }^{\circ} \mathrm{C}}\end{array}$ \\
\hline $\begin{array}{l}\text { Step 2. Reduction of } \mathrm{Sb}^{\mathrm{V}} \\
\text { into } \mathrm{Sb}^{\mathrm{III}} \text { by Cys }\end{array}$ & $\begin{array}{c}{[\mathrm{Cys}]=50 \mathrm{mmol} \mathrm{L}^{-1}} \\
0.25 \leq[\mathrm{Sb}] \leq 5 \mathrm{mmol} \mathrm{L}^{-1} \\
\mathrm{pH} 3,1 \mathrm{~h}, 25-60^{\circ} \mathrm{C}\end{array}$ & $\begin{array}{c}{[\mathrm{Cys}]=50 \mathrm{mmol} \mathrm{L}^{-1}} \\
0.4 \leq[\mathrm{Sb}] \leq 5 \mathrm{mmol} \mathrm{L}^{-1} \\
\text { pH } 3,1 \mathrm{~h}, 60^{\circ} \mathrm{C}\end{array}$ \\
\hline $\begin{array}{l}\text { Step 3. Photometric } \\
\text { determination of } \mathrm{Sb}^{\mathrm{III}}\end{array}$ & \multicolumn{2}{|c|}{$\begin{array}{c}{[\text { Cys }] \leq 2 \mathrm{mmol} \mathrm{L}^{-1} \text { or }[\mathrm{Cys}] /[\mathrm{BPR}] \leq 64} \\
2.5 \mu \mathrm{mol} \mathrm{L}^{-1} \leq[\mathrm{Sb}] \leq 20 \mu \mathrm{mol} \mathrm{L}^{-1}\end{array}$} \\
\hline
\end{tabular}

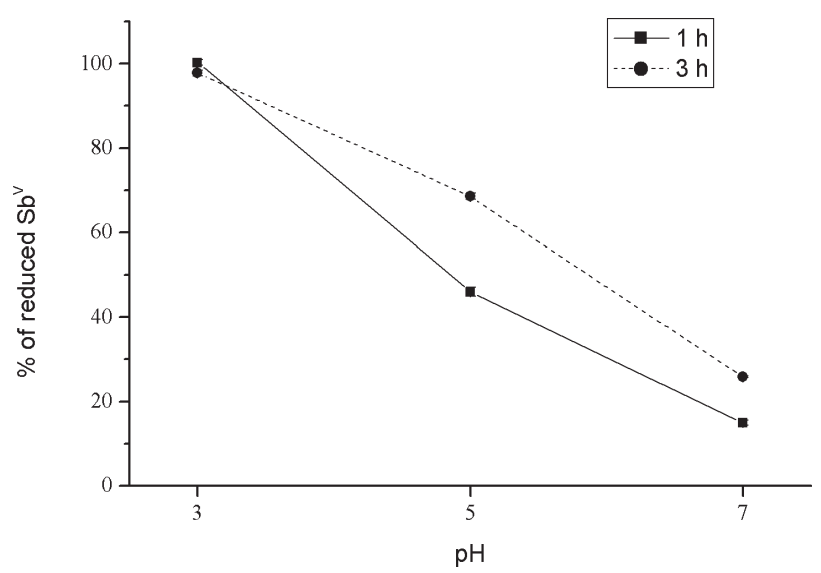

Figure 5. Influence of $\mathrm{pH}$ and reaction time on the reduction efficiency of $\mathrm{Sb}^{\mathrm{v}}$ in the form of meglumine antimoniate by Cys. [Cys] $=50 \mathrm{mmol} \mathrm{L}^{-1}$, $[\mathrm{Sb}]=0.5 \mathrm{mmol} \mathrm{L}^{-1}, \mathrm{pH}=5$. Data are shown as means $\pm \mathrm{SD}(\mathrm{n}=4)$.

being simpler (two-step $v s$. three-step method) and offering a $100 \%$ reduction efficiency of $\mathrm{Sb}^{\mathrm{v}}$.

Application of the reduction reaction of $S b^{v}$ by Cys to the determination of $\mathrm{Sb}$ in liposomal formulations of meglumine antimoniate

We described previously the preparation of liposomal formulations of meglumine antimoniate, DRVs and FDELs, from DSPC, CHOL and DCP (molar ratio of $5: 4: 1)$ in the absence or presence of sucrose, which have been evaluated in dogs for their pharmacokinetics. ${ }^{3}$ Because of the high concentration of lipid in these liposomal preparations and the high phase transition temperature of the phospholipids used in their composition, the acid digestion of these samples is a timeconsuming process. Therefore, there is a great need for simpler and more rapid procedures.

The experimental conditions proposed for the determination of $\mathrm{Sb}^{\mathrm{v}}$ in liposomal meglumine antimoniate are also summarised in Table 1. When compared to the assay used for meglumine antimoniate, an additional step

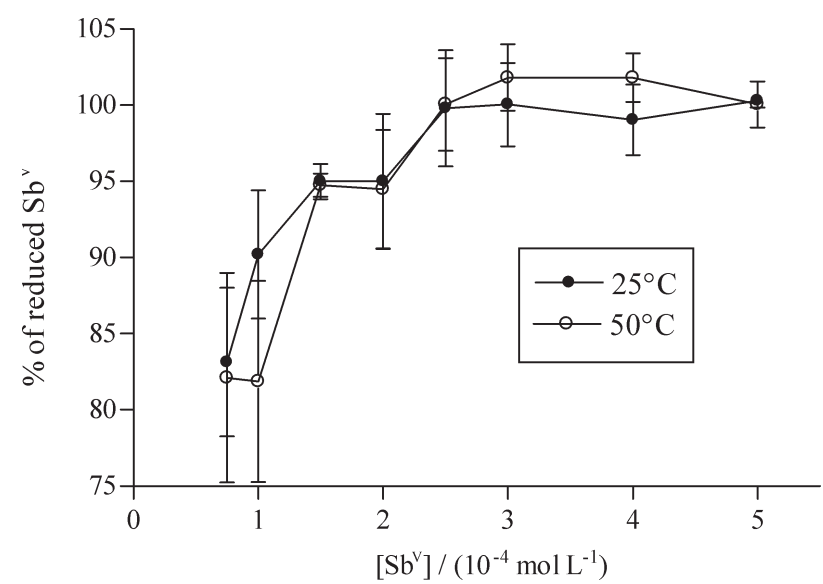

Figure 6. Influence of $\mathrm{Sb}^{\mathrm{V}}$ concentration and temperature on the reduction efficiency of $\mathrm{Sb}^{\mathrm{V}}$ in the form of meglumine antimoniate by Cys. $[\mathrm{Cys}]=50 \mathrm{mmol} \mathrm{L}^{-1}$, time of reaction $=1 \mathrm{~h}$. Data are shown as means $\pm \mathrm{SD}(\mathrm{n}=4)$.

was included to permit the release of encapsulated meglumine antimoniate from liposomes. The temperature of $60{ }^{\circ} \mathrm{C}$ is important to allow for the action of Triton X100 , which is more effective above the phase transition temperature of DSPC $\left(55{ }^{\circ} \mathrm{C}\right)$.

In order to investigate the possible interference of the liposome matrix (method selectivity), samples with varying concentration of $\mathrm{Sb}$ were prepared in water in the absence or presence of empty liposomes at a final lipid concentration of $65 \mathrm{~g} \mathrm{~L}^{-1}$. These samples were treated with Triton X-100 and Cys and were then evaluated by the BPR photometric assay. Figure 7 compares the changes in absorbance as a function of $\mathrm{Sb}$ concentration, in the absence and in the presence of the liposome matrix. Application of the $F$ Test indicated that the variances did not differ significantly. Application of the student $t$ Test showed that the means were not significantly different, demonstrating the absence of interference of the liposome matrix in the photometric assay.

The precision of the method was also evaluated, by calculating the relative standard deviations for measurements performed with samples containing 
Table 2. Precision of the Triton/Cys/BPR method for the determination of $\mathrm{Sb}^{\mathrm{v}}$ concentration in liposomal formulations of meglumine antimoniate ${ }^{\mathrm{a}}$

\begin{tabular}{lccc}
\hline $\begin{array}{l}\text { Sb concentration in } \\
\text { initial preparation / }\left(\mathrm{mol} \mathrm{L}^{-1}\right)\end{array}$ & Mean & $\begin{array}{c}\text { Standard deviation } \\
\text { Relative standard } \\
\text { deviation / }(\%)\end{array}$ \\
\hline 0.04 & 0.1541 & 0.0033 & 2.17 \\
0.08 & 0.3217 & 0.0022 & 0.69 \\
0.12 & 0.4660 & 0.0115 & 2.47 \\
0.16 & 0.6010 & 0.0106 & 1.76 \\
0.2 & 0.7686 & 0.0135 & 1.76
\end{tabular}

The mean and standard deviation refer to the measurement $\left(A_{\mathrm{o}}-A_{\mathrm{m}}\right)$ of 7 preparations, prepared independently, containing empty liposomes at $65 \mathrm{~g} \mathrm{~L}^{-1}$ of lipid; Relative standard deviation $(\%)=($ standard deviation $/$ mean $) \times 100$.

Table 3. Sb concentration values determined in different liposomal formulations of meglumine antimoniate $\mathrm{b}^{\mathrm{a}}$ by the Triton/Cys/BPR method and with the conventional ICP-OES method

Liposomal preparation

$[\mathrm{Sb}] /\left(\mathrm{mol} \mathrm{L}^{-1}\right)$

by Triton/Cys/BPR method

DRV liposomes

DRV liposomes, prepared in the presence of sucrose

FDEL liposomes

FDEL liposomes, prepared in the presence of sucrose

$\begin{array}{ll}0.097 & 0.095 \\ 0.076 & 0.072 \\ 0.067 & 0.069 \\ 0.069 & 0.071\end{array}$

aLiposomal formulations were made from DSPC, CHOL and DCP (molar ratio of 5:4:1) in the absence or presence of sucrose, as described previously. ${ }^{3}$

liposomes $\left(65 \mathrm{~g} \mathrm{~L}^{-1}\right)$ and at different levels of $\mathrm{Sb}$ concentration. Table 2 shows the results of analysis of the method precision. Since the relative standard deviations were inferior to $5 \%$, the method was considered precise.

The accuracy of the method was also satisfactory, since the recoveries of known amounts of $\mathrm{Sb}^{\mathrm{V}}$ after addition to Sb-containing samples and empty liposomes varied between 96 and 104\%. The Sb concentration values determined by the proposed method (Triton/Cys/BPR) and

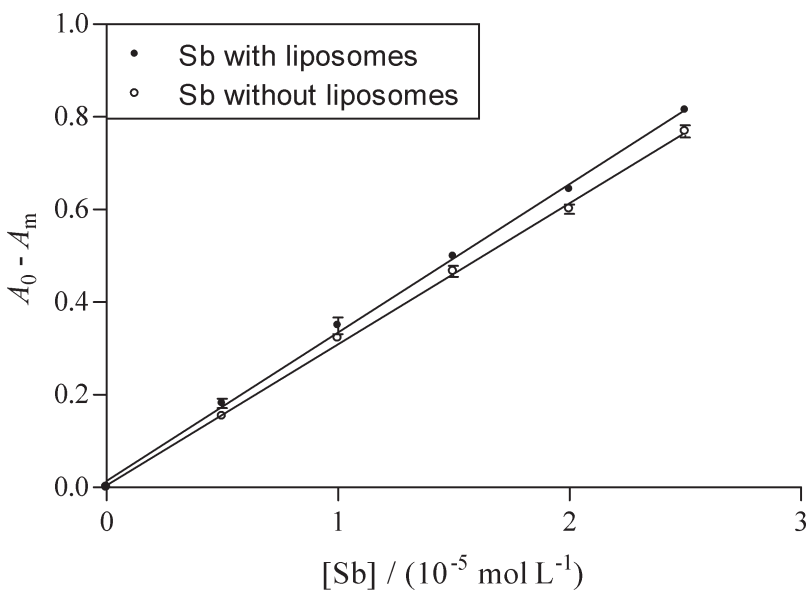

Figure 7. Change in BPR absorbance at $560 \mathrm{~nm}\left(A_{0}-A_{\mathrm{m}}\right)$ as a function of the final $\mathrm{Sb}$ concentration. Samples with varying concentration of $\mathrm{Sb}$ (standard, Titrisol $\left.{ }^{\circledR}\right)\left(0.04,0.08,0.12,0.16\right.$ and $\left.0.2 \mathrm{~mol} \mathrm{~L}^{-1}\right)$ were prepared in water, in the absence or presence of empty liposomes made from DSPC, CHOL and DCP (molar ratio of 5:4:1) at a final lipid concentration of 65 $\mathrm{g} \mathrm{L}^{-1}$. For each $\mathrm{Sb}$ concentration, seven identical samples were prepared independently. These samples were treated with Triton X-100 and Cys, as described in the Experimental Section. Data are shown as means $\pm \mathrm{SD}$ $(\mathrm{n}=7)$. by conventional ICP-OES after nitric acid digestion of the samples are shown in Table 3 for comparison. Importantly, the concentrations of $\mathrm{Sb}$ determined by the two methods were found to be very similar for the four different liposomal formulations.

\section{Conclusions}

In the present work, the reduction reaction of $\mathrm{Sb}^{\mathrm{V}}$ by Cys was kinetically characterized. The reaction orders with respect to $\mathrm{Sb}$ and $\mathrm{Cys}$ were equal to 1.0 and 3.3, respectively. The rate constant for the reaction of reduction was found to be $\mathrm{pH}$-dependent. According to these data, the pharmacological relevance of this reaction depends on the Cys concentration in the macrophage lysosomes. It is suggested that Cys should have a concentration of at least $3 \mathrm{mmol} \mathrm{L}^{-1}$ in order to exert a significant pharmacological role. This reaction was exploited to effectively reduce $\mathrm{Sb}^{v}$ in meglumine antimoniate, for the subsequent photometric determination of $\mathrm{Sb}^{\mathrm{II}}$ using BPR. In the case of meglumine antimoniate, reduction efficiencies of $100 \%$ were achieved at $\mathrm{pH} 3$ in the presence of $50 \mathrm{mmol} \mathrm{L}^{-1}$ Cys and $\mathrm{Sb}$ concentrations higher than $0.25 \mathrm{mmol} \mathrm{L}^{-1}$. The photometric assay was linear in the range of $1.2 \times 10^{-6}$ to $23.5 \times 10^{-6} \mathrm{~mol} \mathrm{~L}^{-1}$ of $\mathrm{Sb}^{\mathrm{III}}$ with a correlation coefficient higher than 0.998 , even in the presence of Cys at a Cys/BPR ratio of 64. Aqueous solutions with $\mathrm{Sb}$ concentration as low as $0.5 \mathrm{mmol} \mathrm{L}^{-1}$ were successfully assayed. The method was also applied to the determination of $\mathrm{Sb}$ in liposomal formulations of 
meglumine antimoniate. In this case, an additional step was introduced before the reduction step, consisting of the Triton X-100-induced release of encapsulated Sb. The latter method showed good precision and accuracy.

\section{Acknowledgments}

This work was supported by the Brazilian agencies, CNPq, MCT, CAPES and FAPEMIG. F.B.O., B.R., D.A.S. and C.S.F. were recipients of studentships from CNPq.

\section{References}

1. Berman, J. D.; Clin. Infect. Dis. 1997, 24, 684.

2. Rath, S.; Jardim, W. F.; Dórea, J. G.; Fresenius J. Anal. Chem. 1997, 358, 548.

3. Frézard, F.; Michalick, M. S. M.; Soares, C. F.; Demicheli, C.; Braz. J. Med. Biol. Res. 2000, 33, 841; Schettini, D. A.; Costa Val, A. P.; Souza, L. F.; Demicheli, C.; Rocha, O. G. F.; Melo, M. N.; Michalick, M. S. M.; Frézard, F.; Braz. J. Med. Biol. Res. 2005, 38, 1879; Frezard, F.; Schettini, D. A.; Rocha, O. G. F.; Demicheli, C.; Quim. Nova 2005, 28, 511; Schettini, D. A.; Ribeiro, R. R.; Demicheli, C.; Rocha, O. G. F.; Melo, M. N.; Michalick, M. S. M.; Frézard, F.; Int. J. Pharm. 2006, 315, 140.

4. Christopher, D. H.; West, T. S.; Talanta 1966, 13, 507.

5. Welz, B.; Sucmanova, M.; Analyst 1993, 118, 1417; Chen, H. W.; Brindle, I. D.; Zheng, S. G.; Analyst 1992, 117, 1603.

6. Gainey, D.; Short, S.; McCoy, K. L.; J. Cell. Physiol. 1996, $168,248$.

7. Alexander, J.; Russell, D. G.; Adv. Parasitol. 1992, 31, 175.

8. Roberts, W. L.; Berman, J. D.; Rainey, P. M.; Antimicrob. Agents Chemother. 1995, 39, 1234.

9. Frézard, F.; Demicheli, C.; Ferreira, C. S.; Costa, M. A. P.; Antimicrob. Agents Chemother. 2001, 45, 913; Ferreira, C. S.; Martins, P. S.; Demicheli, C.; Brochu, C.; Ouellette, M.; Frézard, F.; BioMetals 2003, 16, 441; Yan, S. C.; Li F.; Ding, K. Y.; Sun, H. Z.; J. Biol. Inorg. Chem. 2003, 8, 689.
10. Goodwin, L. C.; Page, J. E.; Biochem. J. 1943, 22, 236; Burguera, J. L.; Burguera, M.; Petit de Pena, Y.; Lugo, A.; Anez, N.; Trace Elem. Med. 1993, 10, 66; Shaked-Mishan, P.; Ulrich, N.; Ephros, M.; Zilberstein, D.; J. Biol. Chem. 2001, 276, 3971.

11. Meister, A.; J. Biol. Chem. 1988, 263, 17205.

12. Fairlamb, A. H.; Cerami, A.; Annu. Rev. Microbiol. 1992, 46, 695.

13. Zhou, Y.; Messier, N.; Ouellette, M.; Rosen, B. P.; Mukhopadhyay, R.; J. Biol. Chem. 2004, 279, 37445; Denton, H.; McGregor, J. C.; Coombs, G. H.; Biochem. J. 2004, 381, 405.

14. Demicheli, C.; Frezard, F.; Lecouvey, M.; Garnier-Suillerot, A.; Biochim. Biophys. Acta 2002, 1570, 192 ; Chai, Y.; Yan, S.; Wong, I. L. K.; Chow, L. M. C.; Sun, H.; J. Inorg. Biochem. 2005, 99, 2257; Demicheli, C.; Santos, L. S.; Ferreira, C. S.; Bouchemal, N.; Hantz, E.; Eberlin, M. N.; Frezard, F.; Inorg. Chim. Acta 2006, 359, 159; Hansen, H. R.; Pergantis, S. A.; Anal. Bioanal. Chem. 2006, 385, 821; Ferreira, C. S.; Pimenta, A. M. C., Demicheli, C., Frezard, F.; Biometals 2006,19, 573.

15. Demicheli, C.; Ochoa, R.; Lula, I. S.; Gozzo, F. C.; Eberlin, M.; Frézard F.; Applied Organomet. Chem. 2003, 17, 226.

16. Loudon, G. M.; J. Chem. Educ.1991, 68, 973.

17. Filella M.; May, P. M.; Geochim. Cosmochim. Acta 2003, 67, 4013.

18. Miekeley, N.; Mortari, S. R.; Schubach, A. O.; Anal. Bioanal. Chem. 2002, 372, 495.

19. Chulay, J. D.; Fleckenstein, L.; Smith, D. H.; Trans. Roy. Soc. Trop. Med. Hyg. 1988, 82, 69.

20. Dzamitika, S. A.; Falcão, C. A. B.; de Oliveira, F. B.; Marbeuf, C.; Garnier-Suillerot, A.; Demicheli, C.; Rossi-Bergmann, B.; Frezard, F.; Chem. Biol. Int. 2006, 160, 217.

21. Sereno, D.; Cavaleyra, M.; Zemzoumi, K.; Maquaire, S.; Ouaissi, A.; Lemesre, J. L.; Antimicrob. Agents Chemother. 1998, 42, 3097.

22. Sun, H. Z.; Yan, S. C.; Cheng, W. S.; Eur. J. Biochem. 2000 , 267,5450 .

Received: June 9, 2006

Published on the web: December 4, 2006 